\title{
ARRAYED WAVEGUIDE GRATING PADA DENSE WAVELENGTH DIVISION MULTIPLEXING
}

\author{
Arkidianabela Anggara Dewi ${ }^{*}$, Teguh Prakoso, dan Aghus Sofwan \\ Departemen Teknik Elektro, Universitas Diponegoro \\ Jl. Prof. Sudharto, SH, Kampus UNDIP Tembalang, Semarang 50275, Indonesia \\ ${ }^{*}$ E-mail: arkidianabela@gmail.com
}

\begin{abstract}
Abstrak
DWDM (Dense Wavelength Division Multiplexing) adalah suatu teknik multiplexing yang mampu mentransmisikan lebih dari 400 panjang gelombang dalam satu serat optik. Laju pengiriman data menggunakan media serat optik dapat mencapai 1 Tbps atau 1.000 Gbps. DWDM merupakan suatu perbaikan dari WDM. Inti perbaikan yang dimiliki oleh teknologi DWDM terletak pada jenis filter, serat optik dan penguat amplifier. Jenis filter yang umum dipergunakan salah satunya adalah Array Waveguide Grating (AWG). Pada Penelitian ini dianalisis kinerja suatu Array Waveguide Filters (AWG) yang mampu digunakan pada DWDM. Pada Penelitian ini dilakukan dengan menggunkan 2 software. Pertama, menggunakan software Optisystem 7 untuk memodelkan sistem DWDM. Kedua, menggunakan software OptiBPM untuk verifikasi AWG. Pada Optisystem didapatkan nilai konfigurasi DWDM yang optimal yaitu pada C Band dengan spasi kanal 50GHz dan jumlah wavelength 64. Sedangkan pada OptiBPM didapatkan untuk konfigurasi DWDM tersebut diperlukan AWG dengan dengan sudut orientasi 53 derajat, panjang FSR 1500um, lebar angular 11,4 derajat dengan ukuran 15000x10000um sehingga didapatkan nilai BER, Q-factor dan crosstalk yang memiliki perbedaan namun telah mencapai kriteria yaitu dengan Q factor antara 8,43 sampai dengan 14,09 sedangkan untuk BER dari $1,719 \times 10^{-40}$ sampai dengan $1,19 \times 10^{-17}$ dan crosstalk antara $-149 \mathrm{~dB}$ sampai dengan $-40,8 \mathrm{~dB}$.
\end{abstract}

Kata Kunci : DWDM,AWG, Crosstalk.

\begin{abstract}
DWDM (Dense Wavelength Division Multiplexig) is a multiplexing technique that capable of transmitting over 400 wavelengths in a single optical fiber. The rate of data transmission using fiber optic can reach 1 Tbps or 1,000 Gbps. DWDM is an improvement of WDM. The essence improvements possessed by DWDM technology is in the type of filter, optical fiber and amplifier amplifier. Common types of filters used are the Array Waveguide Grating (AWG). This final project analyzed the performance of an Array Waveguide Filters (AWG) that capable of being used on DWDM. In this Final Project is done by using 2 software. First, use Optisystem 7 software to model DWDM system. Secondly, use OptiBPM software for AWG verification. In Optisystem, the optimum DWDM configuration value is C Band with $50 \mathrm{GHz}$ channel spacing and 64 wavelength. While in OptiBPM obtained for DWDM configuration AWG is required with orientation angle 53 degree, FSR 1500um length, angular width 11,4 degree with size 15000x10000um to get the value of BER, Q-factor and crosstalk that have differences but has reached the criteria that is with Q factor between 8.43 to 14.09 while for BER from $1,719 \times 10^{-40}$ up to $1,19 \times 10^{-17}$ and crosstalk between $-149 \mathrm{~dB}$ up to $-40.8 \mathrm{~dB}$.
\end{abstract}

Keywords : DWDM,AWG, Crosstalk.

\section{Pendahuluan}

Sistem komunikasi serat optik merupakan sistem komunikasi yang mampu melakukan pengiriman data dalam jumlah besar dengan kehandalan sistem yang baik.. Untuk mendukung kinerja dalam sistem komunikasi serat optik, diperlukan teknik yang menunjang yaitu teknik multiplexing. Salah satunya adalah teknik multiplexing WDM (Wavelength Divison Multiplexing). Namun penggunaan WDM memiliki kelemahan, yaitu ke- nonlinieran serat optik dan efek dispersi yang significant menyebabkan terbatasnya jumlah panjang gelombang yaitu 2 - 8 buah saja [1].

Seiring meningkatnya kebutuhan transmisi data dikembangkan teknik multiplexing yang lain yaitu DWDM (Dense Wavelength Division Multiplexig) yang mampu mentransmisikan lebih dari 400 panjang gelombang dalam satu serat optik. Dimana dari segi 
infrastruktur sendiri praktis hanya terjadi penambahan peralatan pemancar dan penerima saja untuk masingmasing panjang gelombang yang dipergunakan. Inti perbaikan yang dimiliki oleh teknologi DWDM terletak pada jenis filter, serat optik dan amplifier. Jenis filter yang umum dipergunakan di dalam sistem DWDM ini antara lain Dichroic Interference Filters (DIF), Fiber Bragg Gratings (FBG), Array Waveguide Filters (AWG) and Hybrid Fused Cascaded Fiber (FCF) dengan MachZehnder (M-Z)interferometers [2].

Pada teknik multiplexing, dapat digunakan Arrayed Waveguide Grating (AWG) sebagai multiplexer dan demultiplexer dengan jumlah kanal yang besar dan rugirugi yang relatif kecil serta memberikan solusi untuk memperkecil kemungkinan insertion loss dan terjadinya crosstalk seperti yang telah dibuktikan oleh Oplink (2012)[3]. Adapun penelitian lain yang telah dilakukan Amitabha Banerjee (2005) telah menggunakan Arrayed Waveguide Grating (AWG) sebagai teknik multiplexing, [4] tetapi masih belum memberikan hasil yang memuaskan. Selain itu adapun Afif (2013) mengenai analisis performansi AWG pada WDM PON [5]. Kemudian Freza (2015) meneliti tentang perancangan Array Waveguide Grating (AWG) pada jaringan wavelength division multiplexing (WDM) untuk $C$-Band [6] namun mendapatkan nilai crosstalk yang cukup besar. Berdasarkan review tersebut, dalam penelitian ini dibahas mengenai array waveguide grating pada perancangan jaringan DWDM.

\section{Metode}

Pada penelitian ini digunakan beberapa peralatan pendukung, baik berupa perangkat keras maupun perangkat lunak. Perangkat-perangkat yang digunakan antara lain:

1. Personal Computer (PC) dengan sistem operasi 64 bit

2. Microsoft Windows 7 Ultimate

3. Optisystem 7.0

4. OptiBPM

Pada bagian ini dijelaskan mengenai proses perancangan. Pada bagian pertama akan dijelaskan mengenai metodologi penelitian yang dilakukan serta diagram alir dari proses perancangan. Bagian kedua menjelaskan mengenai pembuatan simulasi jaringan serat optik dengan teknologi DWDM menggunakan software Optisystem. Bagian ketiga menjelaskan mengenai penentuan spesifikasi arrayed waveguide grating yang akan digunakan. Bagian keempat akan menjelaskan mengenai verifikasi serta kosimulasi arrayed waveguide grating menggunakan software OptiBPM. Untuk lebih jelas untuk perancangan dijelaskan pada diagram alir perencanaan AWG. Diagram alir proses perencanaan AWG pada DWDM ditampilkan oleh Gambar 1.

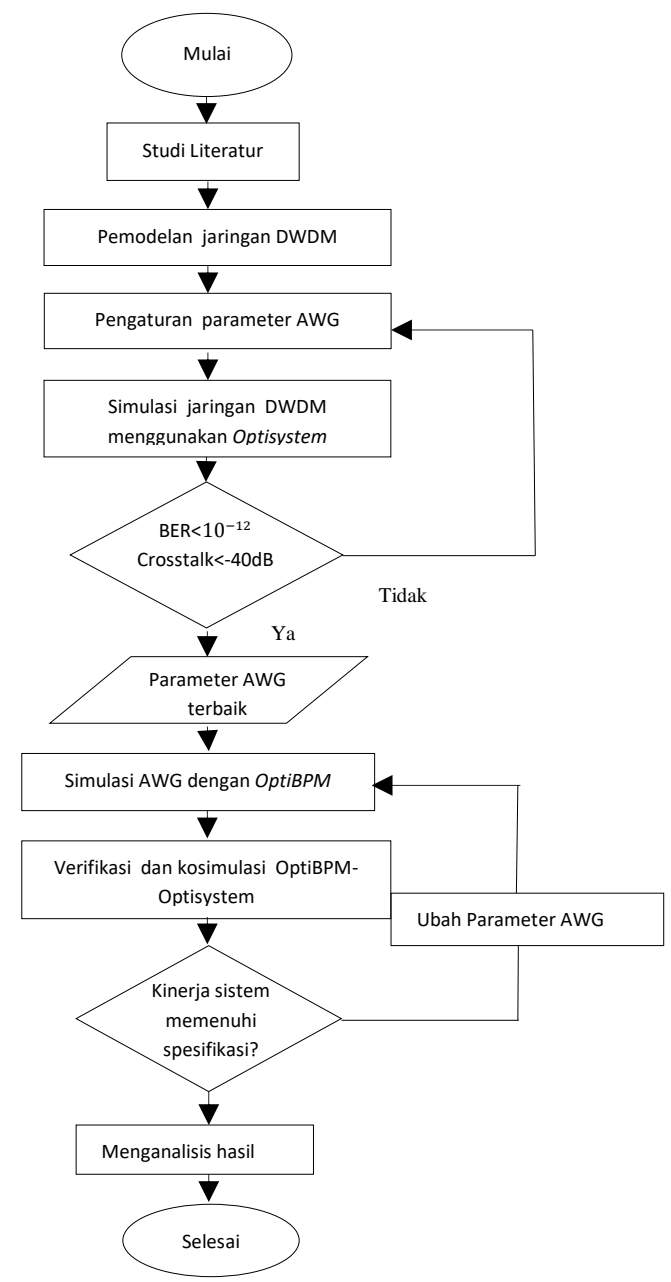

Gambar 1. Diagram alir proses Perencanaan AWG pada DWDM

Skenario yang digunakan dalam Penelitian ini diambil dari spesifikasi sistem DWDM. Spesifikasi tersebut sekaligus merupakan parameter yang digunakan dalam Penelitian ini. Parameter tersebut terdiri dari jumlah wavelength, spasi kanal, dan rentang frekuensi.

\subsection{Desain Sistem DWDM}

Pertama, membuat rancangan model jaringan DWDM dengan menggunakan AWG, akan dilakukan verifikasi terhadap model jaringan yang akan dibuat dengan mengikuti standar ITU-T G697 mengenai DWDM. Model jaringan WDM menggunakan DWDM secara umum dapat dilihat pada Gambar 2. Pada Gambar 2 merupakan Model Jaringan AWG yang tersusun atas transmitter, multiplekser, loop, serat optik, amplifier, dan subsystem 1. Seperti ditunjukan pada Gambar 3 Subsistem1 tersusun atas demultiplekser, optical null, receiver dan BER visualizer dengan jumlah 64 kanal. 


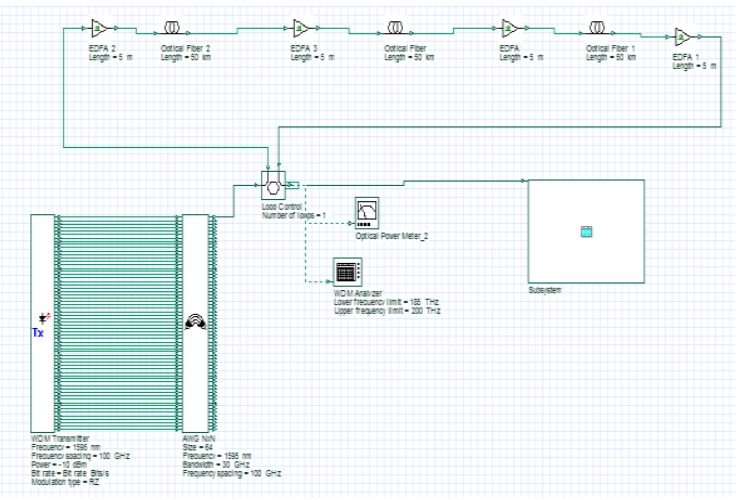

Gambar 2. Model Jaringan DWDM menggunakan AWG pada Optisystem

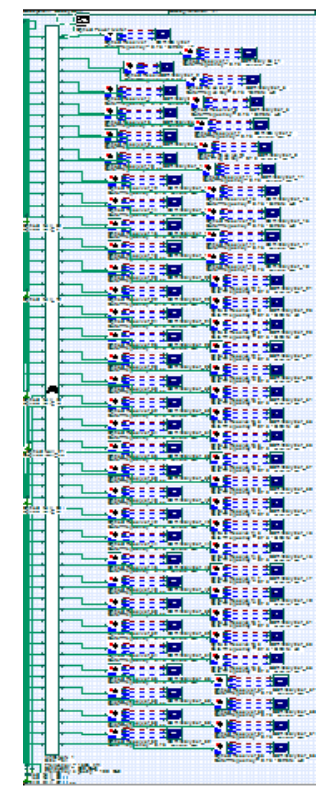

Gambar 3. Subsystem Model Jaringan menggunakan AWG pada Optisystem

DWDM

Setelah melakukan perancangan jaringan menggunakan optisystem dilakukan pengaturan parameter

\subsection{Pengaturan Parameter}

Parameter-parameter yang digunakan dalam memodelkan dan mensimulasikan adalah sebagai berikut. Tabel 1 menunjukan Parameter umum yang digunakan pada Optisystem.

Tabel 1. Global Parameter Pada Optisystem

\begin{tabular}{lll}
\hline Parameter & Nilai & Satuan \\
\hline Bit rate & 2400000000 & Bits/s \\
Time window & $1.28 \mathrm{E}-8$ & $\mathrm{~S}$ \\
sample rate & 160000000000 & $\mathrm{~Hz}$ \\
Sequence length & 64 & $\mathrm{Bits}$ \\
Sample per bit & 32 & \\
Number of sample & 2048 & \\
\hline
\end{tabular}

pengaturan parameter serat optik ditunjukan pada Tabel 2.

Tabel 2. Parameter Serat Optik pada Optisystem

\begin{tabular}{lll}
\hline Parameter & Nilai & Satuan \\
\hline Reference Wavelength & 1550 & $\mathrm{Nm}$ \\
Attenuation & 0.2 & $\mathrm{~dB} / \mathrm{km}$ \\
Length & 100 & $\mathrm{Km}$ \\
Lower Calculation Limits & 1200 & $\mathrm{Nm}$ \\
Upper Calculation Limits & 1700 & $\mathrm{Nm}$ \\
\hline
\end{tabular}

Pengaturan parameter pada WDM transmitter pada Table 3, dimana jumlah output, spasi frekuensi yang akan dicari.

Tabel 3. Parameter WDM Transmitter pada Optisystem

\begin{tabular}{lll}
\hline Parameter & Nilai & Satuan \\
\hline Number of output port & 32,64 & $\mathrm{Bits} / \mathrm{s}$ \\
Frequency & 1550,1595 & $\mathrm{Nm}$ \\
Frequency Spacing & $12.5,50,100$ & $\mathrm{GHz}$ \\
Power & -10 & $\mathrm{dBm}$ \\
Linewidth & 0.1 & $\mathrm{MHz}$ \\
Extinction ratio & 30 & $\mathrm{~dB}$ \\
RIN & -130 & $\mathrm{~dB} / \mathrm{Hz}$ \\
Measured Power & 10 & $\mathrm{dBm}$ \\
\hline
\end{tabular}

Pada parameter multiplexer-nya yang digunakan pada model jaringan ini adalah $\mathrm{AWG} \mathrm{NxN}$, dengan pengaturan parameter pada AWG NxN seperti pada Tabel 4

Tabel 4. Parameter AWG NxN pada Optisystem

\begin{tabular}{lll}
\hline Nama & Nilai & Satuan \\
\hline Size & 32,64 & \\
Configuration & Mux/Demux & \\
Frequency & 1550,1595 & $\mathrm{~nm}$ \\
Bandwidth & 10 & $\mathrm{GHz}$ \\
Frequency & $12.5,50,100$ & $\mathrm{GHz}$ \\
Spacing & & \\
Depth & 100 & $\mathrm{~dB}$ \\
Insertion Loss & 0 & $\mathrm{~dB}$ \\
Filter type & Gaussian & \\
Filter order & 2 & \\
\hline
\end{tabular}

Pada AWG NxN pengaturan konfigurasi pada Optisystem dapat mengubah fungsi dari AWG menjadi multiplexer atau demultiplexer.

\subsection{Perancangan AWG pada OptiBPM}

Proses dalam mensimulasikan AWG digunakan software OptiBPM dikarenakan software Optisystem, yang merupakan software utama pada penelitianini dapat memanggil file OptiBPM. Hal tersebut memudahkan dalam proses kosimulasi. Tahapan pembuatannya adalah sebagai berikut:

\subsubsection{Penentuan Spesifikasi Arrayed Waveguide Grating}

Penentuan Spesifikasi AWG didapatkan dari hasil simulasi pada Optisystem. Dimana pada Optisystem, 
disimulasikan jaringan serat optik menggunakan teknologi DWDM.. Pembuatan AWG dilanjutkan dengan melakukan perhitungan dimensi fisik dari AWG yang bisa didapatkan dari perhitungan secara teoritis.

Berikut merupakan pehitungan jumlah kanal input dan output maksimal juga jumlah waveguide maksimal. Pada perhitungan digunakan indeks refraksi 1,444 dan indeks refraksi group 1,462 karena bahan yang digunakan dalam simulasi AWG menggunakan OptiBPM adalah silica dengan indeks refraksi 1,444.

$$
\begin{aligned}
& \text { 1. Orde Difraksi } \\
& \begin{aligned}
m & =\frac{\lambda_{1}}{\lambda_{1}-\lambda_{2}} \\
& =\frac{1565}{1565-1535} \\
& =43.7143
\end{aligned}
\end{aligned}
$$

2. Perbedaan Panjang Array

$\Delta L=\frac{m \lambda_{0}}{n_{c}} \quad=\frac{43.7143 * 1550}{1.444}=46,923$

3. Panjang Fokal Slab Waveguide

$L_{f}=\frac{d^{2} n_{s} n_{c}}{m \Delta \lambda n_{g}}=\frac{(0,005 n m)^{2} * 1.5 * 1.444}{43.7143 * 0,8 * 1,462}=1059,10$

4. Free Spectral Range

$F S R=\frac{\lambda_{0} n_{c}}{m n_{g}}=\frac{1550 * 1,444}{43,7143 * 1,462}=35,0065$

5. Jumlah Maksimum dari Input/Output Kanal

$$
\begin{aligned}
N_{\text {max }} & =\text { integer }\left(\frac{F S R}{\Delta \lambda}\right) \\
& =\text { integer }\left(\frac{35,0065}{0,8}\right)=44
\end{aligned}
$$

6. Jumlah Arrayed Waveguides

$$
\begin{aligned}
N_{\text {array }} & =4 N_{\max } \\
& =4 \text { integer }\left(\frac{F S R}{\Delta \lambda}\right)=176
\end{aligned}
$$

Pada perhitungan diatas, terlihat nilai dari jumlah kanal maksimal pada range 1535-1565 (C band) dengan spasi kanal $100 \mathrm{GHz}$ atau $0,8 \mathrm{~nm}$ diperoleh maksimal 44 kanal dan maksimal 176 waveguide dan dengan spasi kanal 50 $\mathrm{GHz}$ atau $0,4 \mathrm{~nm}$ diperoleh maksimal 88 kanal dan maksimal 352 waveguide Dalam Penelitian ini dirancang AWG untuk 32 dan 64 kanal sehingga secara perhitungan yang memenuhi syarat untuk 64 kanal adalah spasi kanal $50 \mathrm{GHz}$ dan untuk 32 kanal yang memenuhi syarat adalah $100 \mathrm{GHz}$

\subsubsection{Perancangan Dimensi AWG menggunakan OptiBPM}

Simulasi menggunakan perangkat lunak OptiBPM untuk memvisualisasikan dan mensimulasikan hasil perancangan AWG dengan spesifikasi yang diperoleh dari Optisystem. Gambar 4 menunjukan layout pembuatan rancangan $\mathrm{AWG}$ pada OptiBPM

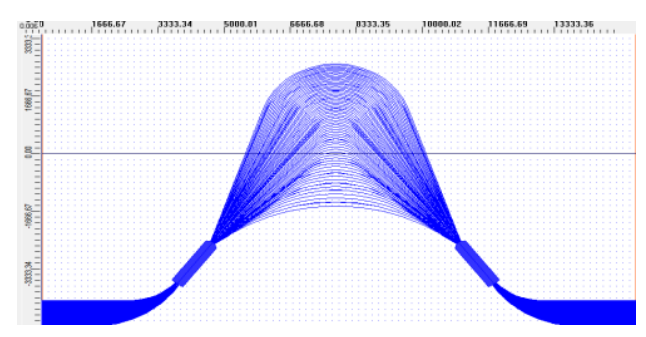

Gambar 4. Layout AWG menggunakan OptiBPM

Setelah membuat layout seperti terlihat pada Gambar 4 langkah selanjutnya mengatur parameter-parameter seperti diperlihatkan pada Tabel 5

Tabel 5. Parameter AWG pada OptiBPM

\begin{tabular}{cc}
\hline Parameter & Nilai \\
\hline IOWgSeparation & 2 \\
PAWgSeparation & 2 \\
CouplerLength & 1500 \\
PAWgLength & 25 \\
IOWgLength & 25 \\
TipSeparation & 8000 \\
InTipPosX & -3766.667 \\
InTipPosZ & 3416.667 \\
Lengthlncrement & 100 \\
InitialLengthIncrement & 500 \\
OrientationAngle & 53 \\
NumberOfPAwgs & 64 \\
AngularWidth & 11.41807 \\
IONumber & 64 \\
PortSeparation & 12 \\
ConnectionOffset & 0 \\
WaferLength & $15000 \mathrm{um}$ \\
WaferWidth & $10000 \mathrm{um}$ \\
WaveguideWidth & $1 \mathrm{um}$ \\
\hline
\end{tabular}

Pada Table 5 merupakan ukuran struktur AWG yang akan dirancang pada optiBPM. Untuk mempermudah dalam pengaturan parameter AWG pada OptiBPM Pada Gambar 5 diperlihatkan gambar keterangan struktur AWG secara umum agar pengaturan parameter-parameternya sesuai.

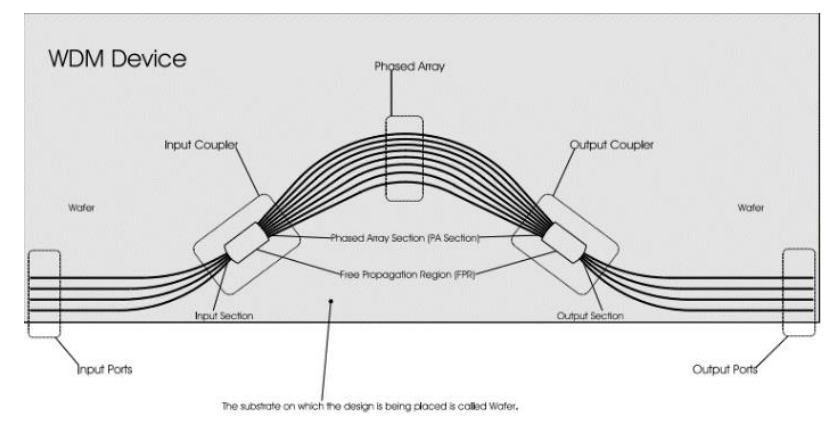

Gambar 5. Struktur AWG secara umum[6]

\subsubsection{Pengujian dan Analisis AWG}

Pengujian AWG yang berupa Perbandingan hasil antara penggunaan AWG hasil simulasi OptiBPM dengan penggunaan AWG pada Optisystem dalam penerapannya 
pada jaringan serat optik dengan teknologi DWDM. Dalam pengujian, Optisystem memanggil file OptiBPM, agar file pada OptiBPM dapat dipanggil ke Optisystem, file OptiBPM yang semula menggunakan format .bpd harus diubah ke format .s.

\section{Hasil dan Analisa \\ 3.1. Hasil Simulasi Optisystem}

Analisa yang dilakukan berdasarkan nilai Bit Error Rate (BER) dan $Q$ factor terlebih dahulu kemudian nilai crosstalk. Nilai toleransi BER untuk sistem DWDM yaitu maksimal $10^{-12}$, kemudian untuk $Q$ factor yaitu minimal 6 , sedangkan untuk crosstalk yaitu maksimal $-40 \mathrm{~dB}$.

Tabel 6. Rekapitulasi hasil simulasi jaringan DWDM menurut BER dan $Q$ factor

\begin{tabular}{|c|c|c|c|c|c|}
\hline No & Band & $\begin{array}{c}\text { jumlah } \\
\text { wavelength }\end{array}$ & $\begin{array}{l}\text { kanal } \\
\text { spasi }\end{array}$ & BER $<-10^{-12}$ & Q Factor $>6$ \\
\hline 1 & \multirow{6}{*}{ C } & \multirow{4}{*}{32} & $12,5 \mathrm{GHz}$ & memenuhi & memenuhi \\
\hline 2 & & & $50 \mathrm{GHz}$ & memenuhi & memenuhi \\
\hline 3 & & & $100 \mathrm{GHz}$ & $\begin{array}{l}\text { IIdak } \\
\text { memenuhi }\end{array}$ & $\begin{array}{c}\text { IIdak } \\
\text { memenuhi }\end{array}$ \\
\hline 7 & & & $12,5 \mathrm{GHz}$ & memenuhi & memenuhi \\
\hline 8 & & \multirow{2}{*}{64} & $50 \mathrm{GHz}$ & memenuhi & memenuhi \\
\hline 9 & & & $100 \mathrm{GHz}$ & $\begin{array}{c}\text { Tidak } \\
\text { memenuhi }\end{array}$ & $\begin{array}{c}\text { Tidak } \\
\text { memenuhi }\end{array}$ \\
\hline 13 & \multirow{6}{*}{$\mathrm{L}$} & \multirow{3}{*}{32} & $12,5 \mathrm{GHz}$ & memenuhi & memenuhi \\
\hline 14 & & & $50 \mathrm{GHz}$ & memenuhi & memenuhi \\
\hline 15 & & & $100 \mathrm{GHZ}$ & $\begin{array}{c}\text { IIdak } \\
\text { memenuhi }\end{array}$ & $\begin{array}{l}\text { IIdak } \\
\text { memenuhi }\end{array}$ \\
\hline 19 & & \multirow{3}{*}{64} & $12,5 \mathrm{GHz}$ & memenuhi & memenuhi \\
\hline 20 & & & $50 \mathrm{GHz}$ & $\begin{array}{l}\text { Tidak } \\
\text { memenuhi }\end{array}$ & $\begin{array}{l}\text { Tidak } \\
\text { memenuhi }\end{array}$ \\
\hline 21 & & & $100 \mathrm{GHz}$ & $\begin{array}{l}\text { Tidak } \\
\text { memenuhi }\end{array}$ & $\begin{array}{l}\text { Tidak } \\
\text { memenuhi }\end{array}$ \\
\hline
\end{tabular}

Pada Tabel 6 terlihat nilai BER dan Q factor pada spasi kanal $100 \mathrm{GHz}$ tidak memenuhi syarat. Hal tersebut dikarenakan nilai dari BER pada beberapa kanal mencapai 1 hal tersebut dikarenakan semakin besar spasi kanal (dengan jumlah input yang sama) orde difraksi dan perbedaan panjang jalur akan turun sedangkan FSR yang dibutuhkan semakin besar, mengakibatkan terjadinya array putus yang menyebabkan nilai BER mencapai 1 .

Begitu pula Dari Tabel 7 didapatkan hampir semua nilai dari spasi kanal $12,5 \mathrm{GHz}$ tidak memehuhi syarat hal tersebut dikarenakan banyak kanal yang crosstalknya tidak mencapai -40dB. Hal tersebut disebabkan oleh semakin kecil spasi kanal maka interferensi akan semakin besar dan menyebabkan crosstalk yaitu adjacent channel crosstalk semakin besar.
Tabel 7. Rekapitulasi hasil simulasi jaringan DWDM menurut crosstalk

\begin{tabular}{ccccc}
\hline kategori & Band & $\begin{array}{c}\text { jumlah } \\
\text { wavelength }\end{array}$ & kanal spasi & Crosstalk<-40dB \\
\hline 1 & & & $12,5 \mathrm{GHz}$ & Tidak memenuhi \\
2 & & 32 & $50 \mathrm{GHz}$ & $\begin{array}{c}\text { memenuhi } \\
\text { memenuhi }\end{array}$ \\
3 & $\mathrm{C}$ & & $100 \mathrm{GHz}$ & $\begin{array}{c}\text { Tidak memenuhi } \\
7\end{array}$ \\
8 & & $64,5 \mathrm{GHz}$ & $50 \mathrm{GHz}$ & memenuhi \\
9 & & & $100 \mathrm{GHz}$ & memenuhi \\
13 & & & $12,5 \mathrm{GHz}$ & Tidak memenuhi \\
14 & & 32 & $50 \mathrm{GHz}$ & memenuhi \\
15 & & & $100 \mathrm{GHz}$ & memenuhi \\
19 & $\mathrm{~L}$ & & $12,5 \mathrm{GHz}$ & Tidak memenuhi \\
20 & & 64 & $50 \mathrm{GHz}$ & Tidak memenuhi \\
21 & & & $100 \mathrm{GHz}$ & memenuhi \\
\hline
\end{tabular}

Tabel 8. Rekapitulasi hasil simulasi jaringan DWDM BER, $Q$ factor dan crosstalk

\begin{tabular}{|c|c|c|c|c|c|}
\hline $\begin{array}{l}\text { kategor } \\
\mathrm{i}\end{array}$ & Band & $\begin{array}{c}\text { jumlah } \\
\text { wavelength }\end{array}$ & kanal spasi & $\begin{array}{l}\text { BER }<-10^{-12} \\
\text { Q Factor }>6\end{array}$ & $\begin{array}{l}\text { Crosstalk<- } \\
40 \mathrm{~dB}\end{array}$ \\
\hline 1 & \multirow{6}{*}{ C } & \multirow{3}{*}{32} & $12,5 \mathrm{GHz}$ & memenuhi & $\begin{array}{l}\text { Tidak } \\
\text { memenuhi }\end{array}$ \\
\hline 2 & & & $50 \mathrm{GHz}$ & memenuhi & memenuhi \\
\hline 3 & & & $100 \mathrm{GHz}$ & $\begin{array}{c}\text { Tidak } \\
\text { memenuhi }\end{array}$ & memenuhi \\
\hline 7 & & \multirow{3}{*}{64} & $12,5 \mathrm{GHz}$ & memenuhi & $\begin{array}{l}\text { Tidak } \\
\text { memenuhi }\end{array}$ \\
\hline 8 & & & $50 \mathrm{GHz}$ & memenuhi & memenuhi \\
\hline 9 & & & $100 \mathrm{GHz}$ & $\begin{array}{c}\text { Tidak } \\
\text { memenuhi }\end{array}$ & memenuhi \\
\hline 13 & \multirow{6}{*}{$\mathrm{L}$} & \multirow{3}{*}{32} & $12,5 \mathrm{GHz}$ & memenuhi & $\begin{array}{l}\text { Tidak } \\
\text { memenuhi }\end{array}$ \\
\hline 14 & & & $50 \mathrm{GHz}$ & memenuhi & memenuhi \\
\hline 15 & & & $100 \mathrm{GHz}$ & $\begin{array}{c}\text { Tidak } \\
\text { memenuhi }\end{array}$ & memenuhi \\
\hline 19 & & \multirow{3}{*}{64} & $12,5 \mathrm{GHz}$ & memenuhi & $\begin{array}{l}\text { Tidak } \\
\text { memenuhi }\end{array}$ \\
\hline 20 & & & $50 \mathrm{GHz}$ & $\begin{array}{c}\text { Tidak } \\
\text { memenuhi }\end{array}$ & $\begin{array}{l}\text { Tidak } \\
\text { memenuhi }\end{array}$ \\
\hline 21 & & & $100 \mathrm{GHz}$ & $\begin{array}{c}\text { Tidak } \\
\text { memenuhi }\end{array}$ & memenuhi \\
\hline
\end{tabular}

Evaluasi berdasarkan variasi parameter yang telah dilakukan desain, dimana dilihat dari Tabel 8 yang memenuhi baik dari BER, Qfactor dan Crosstalk adalah kategori 2 yaitu jumlah wavelength 32 pada band $\mathrm{C}$ pada spasi kanal $50 \mathrm{GHz}$, kategori 8 yaitu jumlah wavelength 64 pada band C pada spasi kanal $50 \mathrm{GHz}$ dan kategori 14 dengan jumlah wavelength 32 pada band L dan spasi kanal $50 \mathrm{GHz}$. Dengan pertimbangan jumlah wavelength yang lebih banyak adalah 64, maka konfigurasi DWDM terbaik adalah jumlah kategori 8 yaitu jumlah wavelength 64 pada band $\mathrm{C}$ dengan spasi kanal $50 \mathrm{GHz}$. 


\subsection{Verifikasi AWG}

Verifikasi AWG menggunakan software OptiBPM. Verifikasi berupa co-simulasi ini bertujuan untuk mengetahui parameter - parameter yang diperlukan pada sebuah jaringan DWDM apakah telah terpenuhi dengan menggunakan AWG yang didapat dari konfigurafi DWDM terbaik tadi dan apakah AWG bener-benar berfungsi sebagai multiplekser untuk memperoleh kinerja DWDM yang optimal. Pada sub bab ini berisi perbandingan dari masing-masing parameter yaitu perbandingan BER, $Q$ Factor, dan Crosstalk dari konfigurasi DWDM terbaik antara ketika menggunakan software Optisystem dan software OptiBPM.

\subsubsection{Perbandingan BER}

Gambar 6 berikut adalah perbandingan antara konfigurasi DWDM terbaik menggunakan software Optisystem dan software OptiBPM berdasarkan nilai BER.

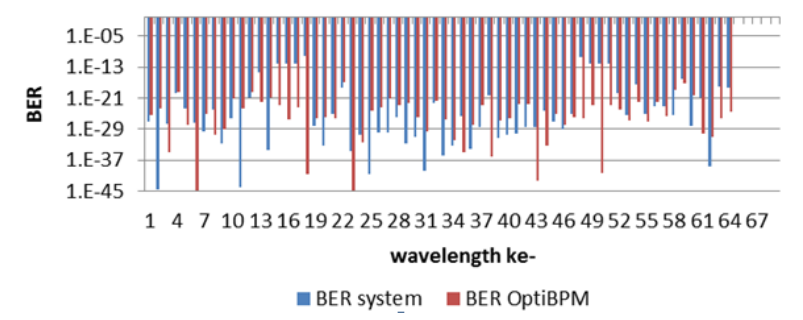

Gambar 6. Perbandingan BER antara AWG dengan Optisystem dan OptiBPM

Dari grafik pada Gambar 6 di atas dapat dilihat bahwa perbandingan antara nilai BER saat menggunakan AWG Opstisystem dan AWG OptiBPM terdapat perbedaan. Hal ini terjadi karena parameter - parameter AWG antara AWG Opstisystem dan AWG OptiBPM tidak sama persis sehingga mengakibatkan perbedaan. Meskipun terdapat perbedaan, keduanya mempunyai nilai BER yang layak yaitu dibawah $10^{-12}$ pada setiap wavelengthnya.

\subsubsection{Perbandingan $Q$ Factor}

Gambar 7 berikut adalah perbandingan antara konfigurasi DWDM terbaik menggunakan software Optisystem dan software OptiBPM berdasarkan nilai $Q$ Factor.

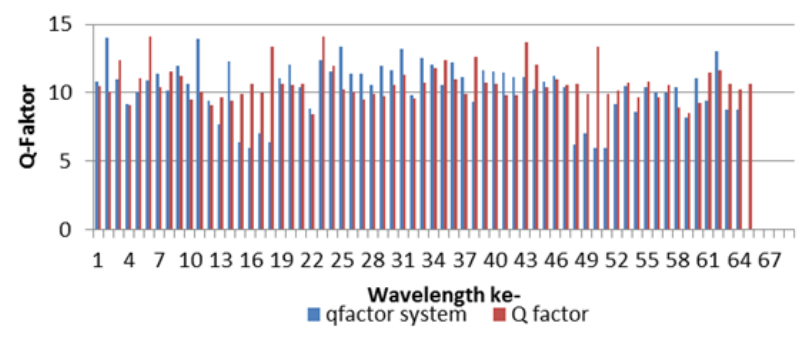

Gambar 7.Perbandingan $Q$ Factor antara AWG dengan Optisystem dan OptiBPM
Dari grafik pada Gambar 7 di atas dapat dilihat bahwa perbandingan antara nilai $Q$ Factor saat menggunakan AWG Opstisystem dan AWG OptiBPM terdapat perbedaan. Hal ini terjadi karena parameter - parameter AWG antara AWG Opstisystem dan AWG OptiBPM tidak sama persis sehingga mengakibatkan perbedaan. Meskipun terdapat perbedaan, keduanya mempunyai nilai $Q$ Factor yang layak yaitu diatas 6 pada setiap wavelength-nya.

\subsubsection{Perbandingan Crosstalk}

Gambar 8 berikut adalah perbandingan antara konfigurasi DWDM terbaik menggunakan software Optisystem dan software OptiBPM berdasarkan nilai crosstalk.

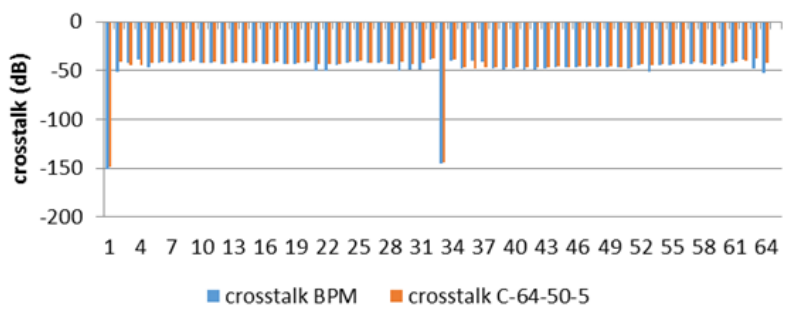

Gambar 8. Perbandingan Crosstalk antara AWG dengan Optisystem dan OptiBPM

Dari grafik pada Gambar 8 di atas dapat dilihat bahwa perbandingan antara nilai crosstalk saat menggunakan AWG Opstisystem dan AWG OptiBPM terdapat perbedaan. Hal ini terjadi karena parameter - parameter AWG antara AWG Opstisystem dan AWG OptiBPM tidak sama persis sehingga mengakibatkan perbedaan. Nilai crosstalk saat menggunakan AWG Opstisystem maupun saat menggunakan AWG OptiBPM sama - sama memiliki nilai crosstalk yang kurang layak yaitu lebih besar dari -40dB.

Di samping perbedaan - perbedaan yang terjadi, secara fungsional untuk verifikasi AWG sudah memenuhi. Hal ini dibuktikan dengan layaknya nilai BER dan $Q$ factor yang berarti AWG benar berfungsi sebagai demultiplekser.

\subsection{Analisis AWG pada Opti BPM}

Pada Analisa AWG, digunakan OptiBPM analyzer, dimana pada sub bab ini dibagi menjadi 2 yaitu mengenai optical field propagation dan refractive index propagation. AWG pada OptiBPM ini dirancang diatas waver dengan ukuran panjang $15000 \mathrm{~nm}$ dan lebar 10000 $\mathrm{nm}$. Untuk lebih jelas, informasi tentang parameternya dapat dilihat pada Tabel 5 dengan hasil

Pada Gambar 9 propagasi disini digunakan Transverse Electric pada pengaturan parameter, yang artinya hanya memancarkan medan magnet pada arah polarisasinya. 


\subsection{Analisis AWG pada Opti BPM}

Pada Analisa AWG, digunakan OptiBPM analyzer, dimana pada sub bab ini dibagi menjadi 2 yaitu mengenai optical field propagation dan refractive index propagation. AWG pada OptiBPM ini dirancang diatas waver dengan ukuran panjang $15000 \mathrm{~nm}$ dan lebar 10000 nm. Untuk lebih jelas, informasi tentang parameternya dapat dilihat pada Tabel 5 dengan hasil

Pada Gambar 9 propagasi disini digunakan Transverse Electric pada pengaturan parameter, yang artinya hanya memancarkan medan magnet pada arah polarisasi nya

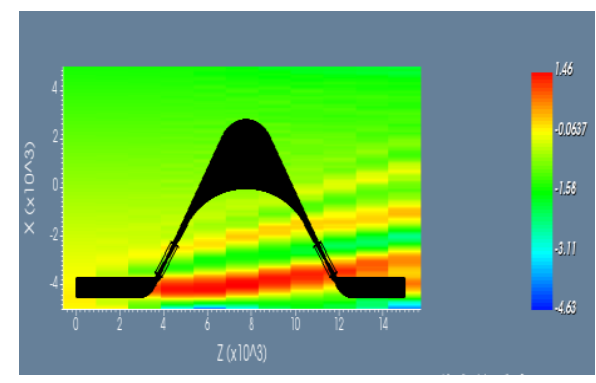

Gambar 9. Optical field Propagation pada AWG

Dimana pada Gambar 9 terlihat nilai polarisasi terkecil bernilai $-3.922 \mathrm{~dB}$ pada posisi -5000 dengan titik potong 15000 , dan nilai tertinggi pada posisi -4000 mencapai 1,46 dengan titik potong 6090 .

\section{Kesimpulan}

Didapatkan nilai untuk konfigurasi jaringan DWDM terbaik adalah dengan jumlah wavelength 64 pada band C dengan spasi kanal $50 \mathrm{GHz}$. Hal tersebut sesuai perhitungan bahwa untuk kanal 64 wavelength diperlukan spasi kanal 50GHz. Setelah dilakukan kosimulasi menggunakan OptiBPM didapatkan nilai BER, Q-factor dan crosstalk yang memiliki perbedaan namun telah mencapai kriteria yaitu dengan $Q$ factor antara 8,43 sampai dengan 14,09 sedangkan untuk BER dari $1,719 \times 10^{-40}$ sampai dengan $1,19 \times 10^{-17}$ dan crosstalk antara $-149 \mathrm{~dB}$ sampai dengan $-40,8 \mathrm{~dB}$ dengan sudut orientasi 53 derajat, panjang FSR 1500um, lebar angular 11,4 derajat dengan ukuran $15000 x 10000 u m$

\section{Referensi}

[1]. Anindita, Adelia Ika. Analisis Kinerja Jaringan DWDM Model Multisite Sederhana Menggunakan Cisco Transport Planner Release. Laporan Tugas Akhir Teknik Elektro Undip. 2014.
[2]. Oplink, "Arrayed Waveguide Grating Multiplexer/Demultiplexer" Oplink Communications Inc, 2012.

[3]. Amitabha Banerjee, dkk, Wavelength-DivisionMultiplexed Passive Optical Network (WDM-PON) Technologies for Broadband Access: a Review [Invited] , Journal of Optical Networking, Vol. 4, No. 11, 2005.

[4]. Saifudin, Afif. Analisa Performansi Arrayed Waveguide Grating (AWG) Pada Jaringan Wavelength Division Multiplexing (WDM) Gigabit-Passive Optical Network (GPON). Laporan Tugas Akhir UIN SUSKA. 2014.

[5]. Hariadi, Frezza Oktaviana. Perencanaan Arrayed Waveguide Grating (AWG) untuk Wavelength Division Multiplexing (WDM) pada C-Band. Laporan Tugas Akhir Teknik Elektro ITS. 2015.

[6]. Manalu, Donda Maria Tiurma. Analisis Perancangan Jaringan Serat Optik DWDM (Dense Wavelength Division Multiplexing) Untuk Link Medan - Langsa. Laporan Tugas Akhir Teknik Elektro Universitas Sumatra Utara. 2012.

[7]. Optical Monitoring for dense wavelength division multiplexing: General Characteristics, ITU-T Standard G. 697,2018 .

[8]. ITU, " Optical fibre, cables and systems" Agrawal G. P., Fiber-Optic Communication Systems, 3rd Edition. New York: John Wiley \& Sons, 2002.

[9]. P. Ignatia G. D., "Perancangan Jaringan Akses Fiber to the Home (FTTH) dengan Teknologi Gigabit Passive Optical Network (GPON) di Private Village, Cikoneng", Tugas Akhir, Fakultas Teknik Elektro, Universitas Telkom, Bandung, 2015.

[10]. Keiser G., Optical Fiber Communication, 4th Edition. Singapore: McGraw-Hill, 2008.

[11]. Arrayed Waveguide Grating. OptiBPM Operations Guide. USA : OptiBPM, Inc. 2012.

[12]. Gerd Keiser, "Optical Fiber Communication third edition”, Mc Graw Hill International Edition, 2000

[13]. Research Centre for Microtechnology "Arrayed Waveguide Gratings: tiny structures for big ideas, Application Note, FHV Research" DWDM 05, 2010

[14]. Gerd Keiser, "Optical Fiber Communication 4th edition", Mc Graw Hill International Edition, 2010

[15]. Gigabit-capable Passive Optical Networks (GPON): Gigabit-Capable Passive Optical Network (G-PON): General Characteristics, ITU-T Standard G.984.1, 2008.

[16]. Gigabit-capable Passive Optical Networks (GPON): Physical Media Dependent (PMD) layer specification, ITU-T Standard G.984.2, 2003.

[17]. Gigabit-Capable Passive Optical Network (G-PON): Transmission Convergence Layer Spesification, ITU-T Standard G.984.3, 2014.

[18]. Gigabit-capable Passive Optical Networks (GPON): Gigabit-Capable Passive Optical Network (G-PON): ONT Management and Control Interface Specification, ITU-T Standard G.984.4, 2008. 